\title{
Mapping the Spatial Distributions of Water Quality and Their Interpolation with Land Use/Land Cover Using GIS and Remote Sensing in Noyyal River Basin, Tamil Nadu, India
}

\author{
Geetha Selvarani Arumaikkani1 ${ }^{*}$, Sivakumar Chelliah², Maheswaran Gopalan ${ }^{3}$ \\ ${ }^{1}$ Department of Civil Engineering, K.S.R. College of Engineering, Namakkal District, Tamil Nadu, India \\ ${ }^{2}$ Department of Mechanical Engineering, K.S.R. College of Engineering, Namakkal District, Tamil Nadu, India \\ ${ }^{3}$ VSA Group of Institutions, VSA School of Engineering \& Management Salem, Tamil Nadu, India \\ Email: ${ }^{*}$ geethacivil1201@gmail.com
}

How to cite this paper: Arumaikkani, G.S., Chelliah, S. and Gopalan, M. (2017) Mapping the Spatial Distributions of Water Quality and Their Interpolation with Land Use/Land Cover Using GIS and Remote Sensing in Noyyal River Basin, Tamil Na$\mathrm{du}$, India. Journal of Geoscience and Environment Protection, 5, 211-220.

https://doi.org/10.4236/gep.2017.58017

Received: June 19, 2017

Accepted: August 6, 2017

Published: August 9, 2017

Copyright $\odot 2017$ by authors and Scientific Research Publishing Inc. This work is licensed under the Creative Commons Attribution International License (CC BY 4.0).

http://creativecommons.org/licenses/by/4.0/

\begin{abstract}
Noyyal River is historically, ecologically and culturally significant river in Kongu region of western Tamilnadu. More than 100 villages are situated along the banks of the Noyyal River and it's the was the best site of inhabitation on both the sides of the river up to $3 \mathrm{~km}$ from the river before the emergence of the issue of industrial pollution. But now river Noyyal was highly polluted by domestic and industrial growth by discharging of both domestic and industrial are discharged without any treatment. So methodology was proposed to identify the suitable zone for groundwater quality by using land use/land cover data along with groundwater quality in analytic hierarchy process. Suitability of groundwater for drinking was identified in the study area by collecting 63 samples in both postmonsoon and premonsoon as per Indian standards. To evaluate the land use pattern of the study area, land use/land cover map was prepared from satellite images of LISS III by using supervised classification according to National Remote Sensing Agency (NRSA) using Erdas imagine 8.4 software. Using ArcGIS software, weighted overlay analyses were carried out to identify the suitable zones for groundwater quality in postmonsoon and premonsoon and finally these two thematic maps were integrated with land use/land cover map to identify the suitable zone for quality of water. The interpretation shows that groundwater in most of the locations were unsuitable for drinking purposes.
\end{abstract}

\section{Keywords}

Noyyal River, Drinking Water Quality, Total Dissolved Solids, GIS, Land Use 


\section{Introduction}

Groundwater is a vital natural resource and it is used for drinking, irrigation and industrial purposes. Nowadays the quality of groundwater is deteriorating day by day due to over exploitation of groundwater and improper methods of solid waste disposal and untreated effluents into the water bodies [1] [2] [3]. And also the temporal changes in the origin and constitution of the recharged water, hydrologic and human factors may cause periodic change in groundwater quality. And this water pollution not only affects water quality but also threatens human health, economic development, and social prosperity. Hence, evaluation of groundwater quality status for human consumption is important for socio-economic growth, development and also for establishing a database for planning future water. Mapping the spatial distributions of major elements and their interpolation with the geology and land use/land cover maps in GIS environment [4] [5] have contributed for the better understanding of the chemical processes of water and the methods of their acquisition. Several studies were carried out in the past two decades for identifying the groundwater quality zones using GIS and remote sensing data and the methodology proposed in the literature are [6]-[18]. Noyyal River is one of the tributaries of the river Cauvery, which originates from the hills of Vellingiri, also termed as southern Kailayam in Western Ghats and flows towards the southwest of Coimbatore district in Tamil $\mathrm{Nadu}$, and finally it ends in river Cauvery at Kodumudi in Karur district. It flows through Coimbatore, Tiruppur, Erode and Karur districts with its catchments in seven taluks (Coimbatore, Tiruppur, Avinashi, Palladam, Dharapuram, Erode and Karur). It flows over a length of about $180 \mathrm{Kms}$ covering an area of 3510 $\mathrm{km}^{2}$. Out of the total area in the basin, $1752 \mathrm{~km}^{2}(49.9 \%)$ of the area is under cultivation and $178 \mathrm{~km}^{2}(5.1 \%)$ is covered by forest and wetland growing teak and eucalyptus and the rest $1580 \mathrm{~km}^{2}(45 \%)$ is barren land [19]. The boundary of the river basin is between north latitude $10^{\circ} 54^{\prime} 00^{\prime \prime}$ to $11^{\circ} 19^{\prime} 03^{\prime \prime}$ and east longititude $76^{\circ} 39^{\prime} 30^{\prime \prime}$ to $77^{\circ} 55^{\prime} 25^{\prime \prime}$ which is shown in Figure 1 . More than 100 villages are

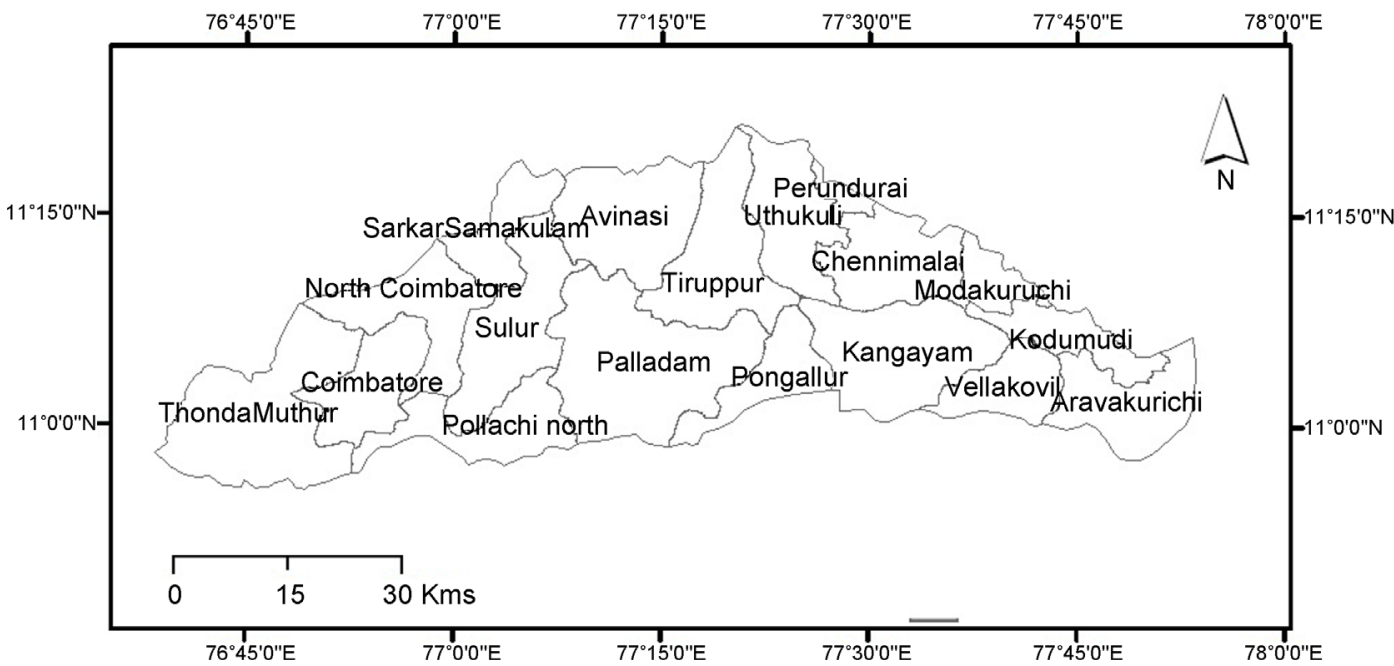

Figure 1. Key plan showing the study area details. 
situated on both sides of the banks of river Noyyal. Nearly 6000 acres of cultivable land in Coimbatore district is irrigated by using river water [20].

The average rainfall in the basin is about $700 \mathrm{~mm}$. The river flows from west to east and its maximum elevation is around $1600 \mathrm{~m}$ above mean sea level and the minimum elevation is $100 \mathrm{~m}$ above mean sea level [21]. It is also believed that water contains natural medicine and therefore it is good for health. Noyyal is a seasonal river which has good flow only for short periods during the northeast and southwest monsoons. Occasionally flash floods occur when there is heavy rain in the catchment areas [22]. Apart from these periods, there is only scanty flow in most part of the year. Generally, a subtropical climate condition prevails in the river basin. It is divided into, winter from January to February, summer from March to May and it is followed by southwest monsoon from June to September and from October to December constituting the postmonsoon season [21]. The rainfall in western parts is comparatively more during the southwest monsoon season while the eastern parts get more rainfall during the northeast monsoon season [23]. The precipitation is unevenly distributed throughout the year and often completely lacking of rainfall during dry period [23]. The present study is to evaluate the physico-chemical characteristics of groundwater in and around a Noyyal River basin and integrated with land use/land cover data for the assessment and suitability of groundwater for drinking purposes.

\section{Materials and Methods}

The base map of the study area was created by using Survey of India (SOI) toposheets of $58 \mathrm{~A} / 12,58 \mathrm{~A} / 16,58 \mathrm{~B} / 9,58 \mathrm{~B} / 13,58 \mathrm{E} / 3,58 \mathrm{E} / 4,58 \mathrm{E} / 7,58 \mathrm{E} / 8,58 \mathrm{E} / 12$, $58 \mathrm{E} / 16,58 \mathrm{~F} / 1,58 \mathrm{~F} / 5,58 \mathrm{~F} / 9,58 \mathrm{~F} / 13$ (1:50,000). Sixty three groundwater (bore well) samples were collected in a cleaned polythene bottle in and around the catchments of the basin during the month of January 2015 (postmonsoon) and June 2015 (premonsoon) to know the status of various physico-chemical parameters and their impacts. The sampling locations were marked in the base map which is shown in Figure 2 and its corresponding names are given in the Table 1. Standard procedure and methods were followed for preservation and analysis of the groundwater samples [24]. The analysed results were compared with Indian Standard (IS) 10,500-1991 [25]. The suitability of groundwater for drinking was identified based on Total Dissolved Solids (TDS), chlorides, calcium, hardness and alkalinity for both postmonsoon and premonsoon.

Using ArcGIS software, weighted overlay analyses were carried out to identify the suitable zones for groundwater quality in postmonsoon and premonsoon and finally these two thematic maps were overlaid to identify the suitable zones for Drinking purposes. This analysis has categorised the study area into three zones (good, moderate and poor), which would enable the user to locate the potable water without any problem which is shown in Table 2. Each class in every thematic map was assigned a weight. Highest weight was assigned to the class that was most favourable for the drinking and the lowest weight was assigned to the class that was least favourable/unfavourable class. To evaluate the 


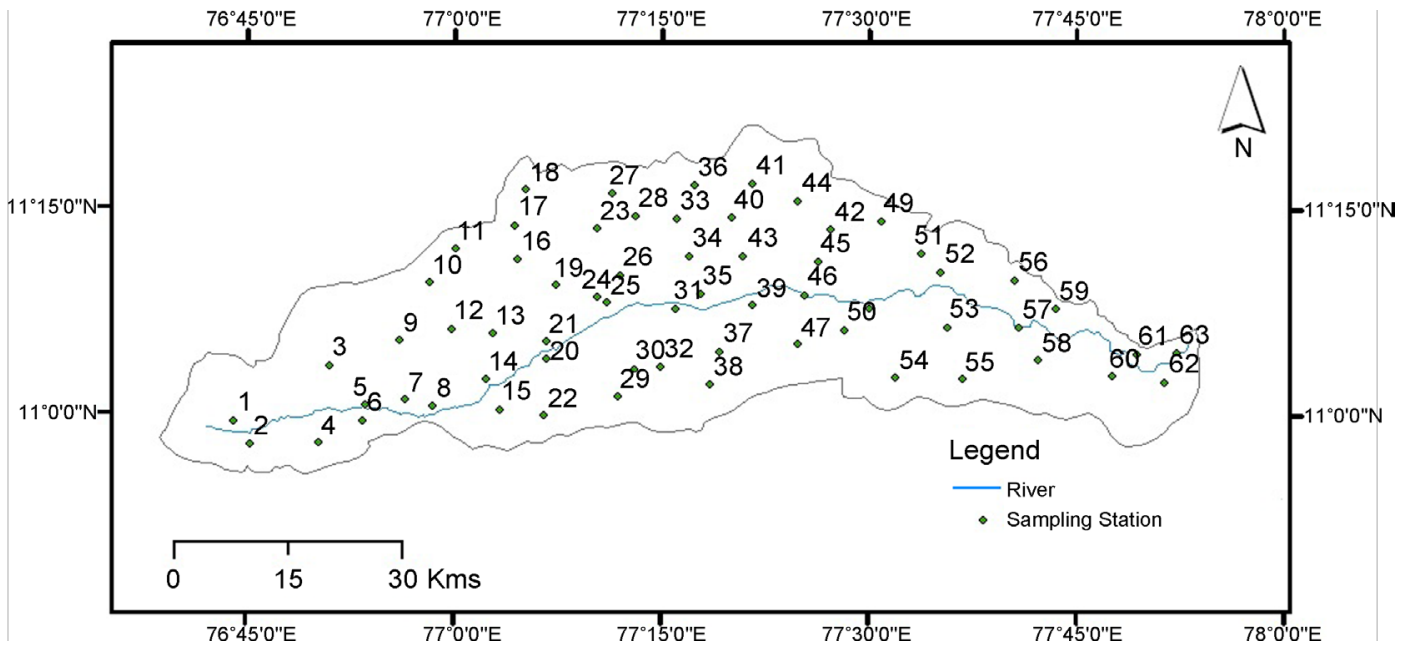

Figure 2. Key plan showing sampling stations.

Table 1. Details of the sampling locations.

\begin{tabular}{|c|c|c|c|}
\hline Sl.No & Name of Habitation & Sl.No & Name of Habitation \\
\hline S1 & Iruttupallam & S2 & Perumalswamykovil \\
\hline S3 & Thimmekavanporam & S4 & Mathipalayam \\
\hline S5 & Perur & S6 & Ramachattipalayam \\
\hline S7 & Ukkadam & S8 & Nanjundapuram \\
\hline S9 & Varadayyampalayam & S10 & Kalappatti \\
\hline S11 & Karaiyampalayam & $\mathrm{S} 12$ & Irugur \\
\hline S13 & Pattanampudur & S14 & Kariyampalayam \\
\hline S15 & Indiranagar & S16 & Alampalaiyam \\
\hline S17 & Sulur & S18 & Muttukavundampudur \\
\hline S19 & Rasipalayam & $\mathrm{S} 20$ & Apanayakkanpattipudur \\
\hline S21 & Uppilipalayam & S22 & Puduppalayam \\
\hline S23 & Karumattampatti & S24 & Senniyandavarkovil \\
\hline S25 & Semmandampalayam & S26 & Vellandipalayam \\
\hline S27 & Periyakattupalayam & S28 & Arangattupalayam \\
\hline S29 & Ayyampalayam & $\mathrm{S} 30$ & Rasakkaundampalayam \\
\hline S31 & Mangalam & $\mathrm{S} 32$ & Rasakavundanpalayam \\
\hline S33 & Nallikavundapalayam & S34 & Tirumuruganpundi \\
\hline S35 & Murugapalayam & S36 & Karuvampalayam \\
\hline S37 & Chennimalaipalayam & S38 & Krishnapuram \\
\hline S39 & Nallur & S40 & Perumanallur \\
\hline S41 & Uttukkuli & S42 & Molakavundampuam \\
\hline S43 & Velampalaiyam & S44 & Aruvangattupuram \\
\hline S45 & Periyakunnampalayam & S46 & Manur \\
\hline S47 & Kariyampalayam & S48 & Ramakkaranpalayam \\
\hline S49 & Kavundanpalayam & S50 & Moskuttivalasu \\
\hline S51 & Chennimalai & S52 & Puchchakkattuvalasu \\
\hline S53 & Pallakkatupudur & S54 & Uttamapalayam \\
\hline S55 & Palanikavundanvalasu & S56 & Vettukattuvalasu \\
\hline S57 & Sengodampalayam & S58 & Subramaniyapuram \\
\hline S59 & Valliyampalayam & S60 & Velliyankattupudur \\
\hline S61 & Murugampalayam & S62 & Adiyappakaundanvalasu \\
\hline S63 & Velaiyampalayam & & \\
\hline
\end{tabular}


Table 2. Criteria for the classification of thematic maps of groundwater quality and land use/land cover for drinking purpose.

\begin{tabular}{|c|c|c|c|c|}
\hline S.No & Parameters & Descriptive scale & Score & Weightage \\
\hline \multirow{3}{*}{ 1) } & \multirow{3}{*}{ Hardness (mg/l) } & Good & 3 & \multirow{3}{*}{20} \\
\hline & & Moderate & 2 & \\
\hline & & Poor & 1 & \\
\hline \multirow{3}{*}{ 2) } & \multirow{3}{*}{ TDS (mg/l) } & Good & 3 & \multirow{3}{*}{30} \\
\hline & & Moderate & 2 & \\
\hline & & Poor & 1 & \\
\hline \multirow{3}{*}{ 3) } & \multirow{3}{*}{ Calcium (mg/l) } & Good & 3 & \multirow{3}{*}{5} \\
\hline & & Moderate & 2 & \\
\hline & & Poor & 1 & \\
\hline \multirow{3}{*}{ 4) } & \multirow{3}{*}{ Alkalinity (mg/l) } & Good & 3 & \multirow{3}{*}{10} \\
\hline & & Moderate & 2 & \\
\hline & & Poor & 1 & \\
\hline \multirow{3}{*}{ 5) } & \multirow{3}{*}{ Chlorides (mg/l) } & Good & 3 & \multirow{3}{*}{5} \\
\hline & & Moderate & 2 & \\
\hline & & Poor & 1 & \\
\hline \multirow{9}{*}{ 6) } & \multirow{9}{*}{ Land use/Land cover } & Land with scrub & 3 & \multirow{9}{*}{30} \\
\hline & & Crop land & 3 & \\
\hline & & Fallow land & 3 & \\
\hline & & Scrub forest & 2 & \\
\hline & & Built up land & 1 & \\
\hline & & Water bodies & 3 & \\
\hline & & Land without scrub & 3 & \\
\hline & & Forest blank & 2 & \\
\hline & & Open forest & 2 & \\
\hline
\end{tabular}

land use pattern of the study area, land use/land cover map was prepared from satellite images of LISS III by using supervised classification according to National Remote Sensing Agency (NRSA) [26] with Erdas imagine 8.4 software. Finally land use/land cover map was integrated with quality map to identify the suitable zone for quality of water.

\section{Result and Discussion}

By means of ArcGIS superimpose was prepared by adding up the weights of the classified themes of postmonsoon, premonsoon and land use/land cover map were used to prepare a map of groundwater quality zone for drinking purpose of the study area.

Overlaying was done by adding the weights of the classified themes of hardness, TDS, alkalinity, chlorides and calcium were used to prepare a map of groundwater quality for drinking purpose in ArcGIS platform. This analysis has categorized in the study area into three zones (good, moderate and poor). The 
spatial variation of suitable zones for drinking purposes based on groundwater quality for both postmonsoon and premonsoon are shown in Figure 3 and Figure 4. GIS analysis, reveals that the quality of groundwater was predominantly poor category in both premonsoon and postmonsoon, while the good category water found in Thondamuthur block during premonsoon period. The suitable quality found in southwestern, western and southeastern side of the river basin. The discharging of industrial and Drinking effluent on either side of the river were ultimately polluting the groundwater of the study area and this reflects in the downstream of Tiruppur during premonsoon period and also the potable ground water was found in larger area than during the postmonsoon period.

Land is a prime natural resource and the mapping of land use/land cover is essential for planning and development of land and water resources [27]. But anthropogenic and natural forces modify the landscape. So it is important to monitor and assess these alterations to avoid the misuse of usable land into wastelands. Timely and accurate information on the existing land use/land cover

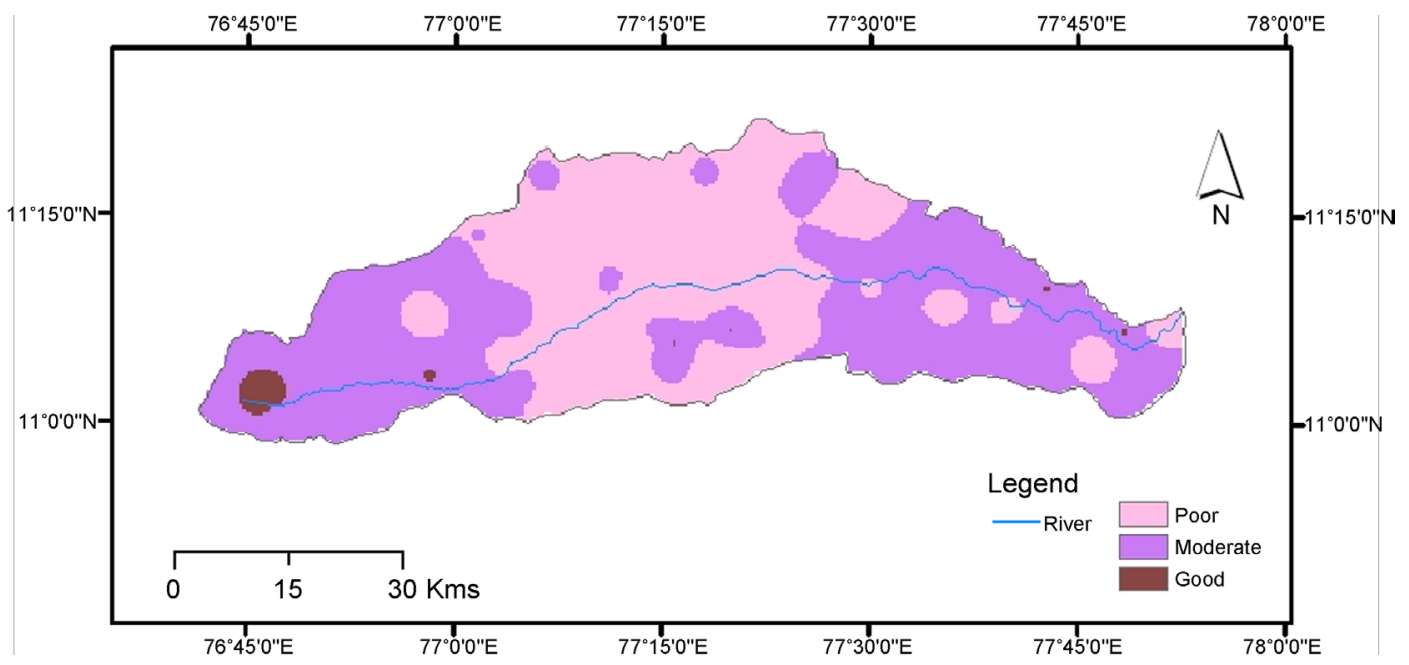

Figure 3. Spatial distribution of groundwater quality for drinking in postmonsoon.

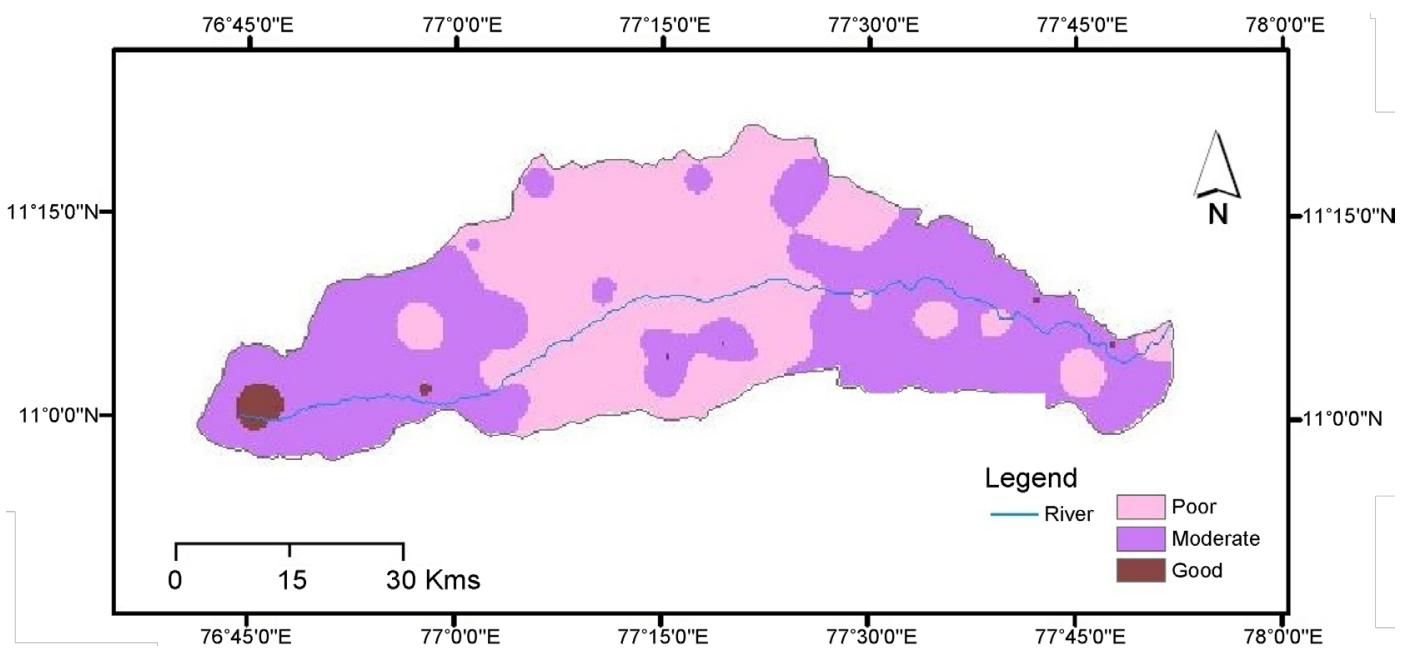

Figure 4. Spatial distribution of groundwater quality for drinking in premonsoon. 
pattern and its spatial distribution and changes is a prerequisite for planning, utilisation and formulation of policies and programmes for making micro and macro-level developmental plan [27]. Remote sensing technology along with GIS is cost-effective and best utilised solutions for integration of various data sets for both macro and micro level analysis which helps in identifying the problem areas and suggest conservation measures [6] [7]. The mapping and monitoring of the land use/land cover requires land use classification system. One of the most widely used classification scheme was developed by National Remote Sensing Agengy (NRSA 1995) [26]. Land use/land cover change detection mapping of the study area has been done by using software ERDAS Imagine 8.4 from Landsat TM and IRS LISS III data. The ten major levels of land use/land cover categories were interpreted in the image of the study area and is shown in Figure 5 namely built up land having poor sanitary conditions and anthropogenic activities, groundwater quality is deteriorating significantly in the city area as compared to water fields so it has poor groundwater quality zone, fallow land and agriculture land, land with scrub, land without scrub, water bodies fields facilitate the recharge of groundwater during monsoon periods and also provide the water supply to city through production wells [6] [7]. So it has very good groundwater quality zone, dense forest, scrub forest, forest blank and open forest having moderate groundwater zone.

In the study area, groundwater quality map was prepared by overlaying and adding a weightage of classified themes from postmonsoon, premonsoon and land use/land cove map. This analysis has categorized the study area into three zones (good, moderate and poor). The spatial variation for drinking purpose (Figure 6) based on the thematic map was found under moderate category in south western, eastern and north eastern side of the study area, while good category water was found in Thondamuthur block in south eastern side of the study area. Poor category was found in southern, centre and northern parts of the study area. The highly polluted blocks were Annur, Avinashi, Tiruppur, Sulur,

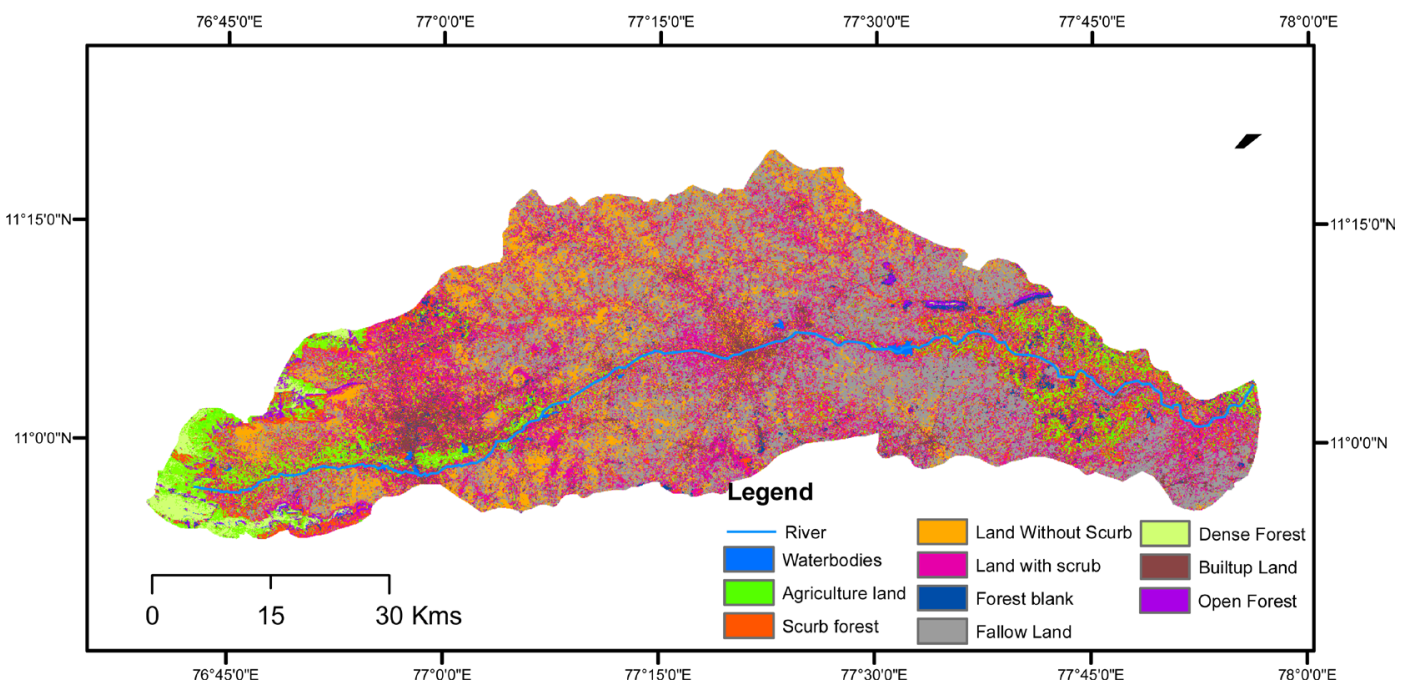

Figure 5. Land use classification. 


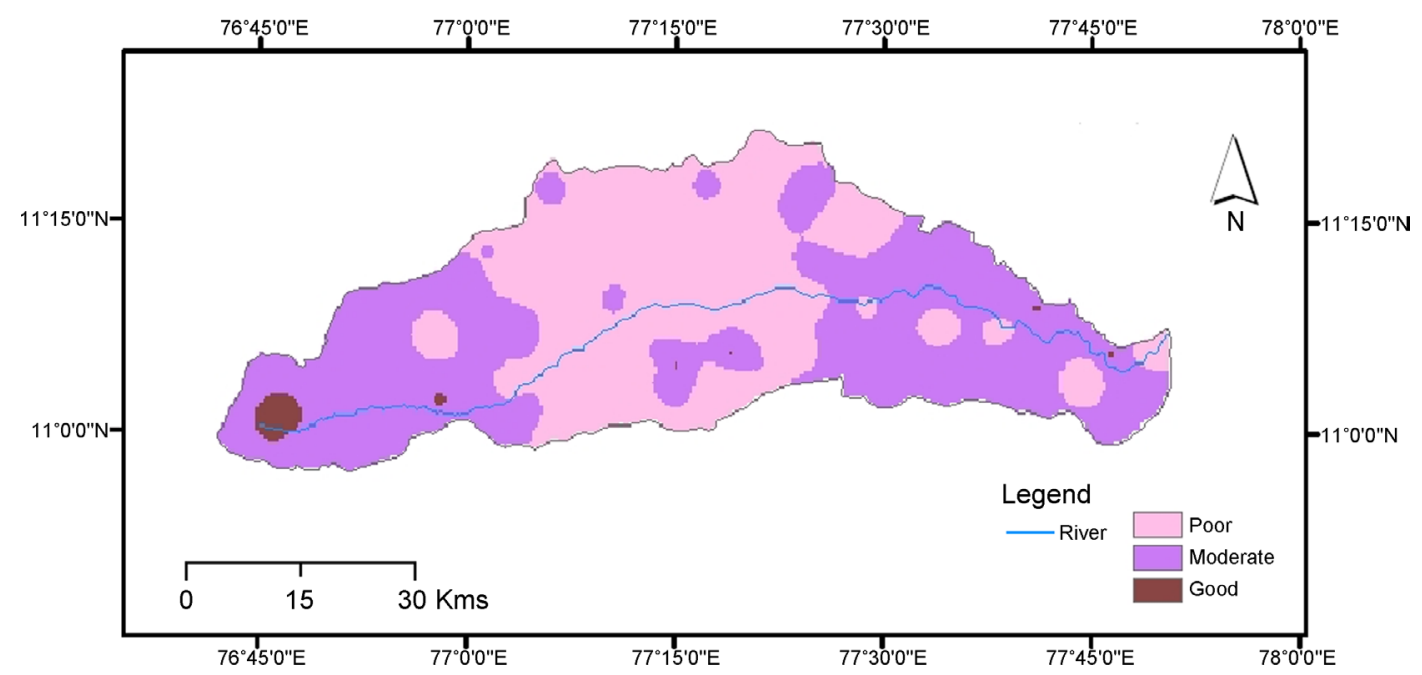

Figure 6. Spatial distribution of groundwater quality showing suitable zone for drinking.

Sultanpet, Palladam, Pongalaur, Uthukuli and few isolated parts of Kangeyam and Perundurai blocks.

\section{Conclusion}

Geospatial techniques are applied to identify and assess the groundwater quality zones for drinking purposes. The quality zone is assessed by integrating water quality map and land use/land cover map with categorized into good, moderate and poor. The spatial distribution shows that the percentage of suitable zones for drinking is higher in postmonsoon as compared to premonsoon due to high recharge and dilution of contaminants during monsoon and postmonsoon. Based on the interpretation, groundwater quality of Noyyal river basin is not suitable in few locations for drinking purposes and also indicates that, the river is heavily polluted only after entering the Sarkar Samakulam area of Coimbatore district and continues till the end of the basin. The drinking water quality is deteriorated at some sites which is indicated by the excess presence of total dissolved solids, hardness, alkalinity and chloride which is due to dense population and discharge of industrial and drinking effluents. So groundwater in these locations can be used for irrigation under special circumstance only. If the improper disposal of municipal and industrial waste is continuously falling in the Noyyal river basin, then there is a chance for over pollution in future, which affects the aquifer system of the basin to a greater extent.

\section{References}

[1] de A. Eunice, M., Helba, A.Q.P., Ivam, H.S., de O.L. Raimundo, A. and Maria, J.G. (2008) Land Use Effects in Groundwater Composition of an Alluvial Aquifer (Trussu River, Brazil) by Multivariate Techniques. Environmental Research, 106, 170-177. https://doi.org/10.1016/j.envres.2007.10.008

[2] Yammani, S. (2007) Groundwater Quality Suitable Zones Identification: Application of GIS, Chittoor Ara, Andhra Pradesh, India. Environmental Geology, 53, 201 
210. https://doi.org/10.1007/s00254-006-0634-1

[3] Bridget, R.C. and Reedy, C.R. (2005) Impacts of Land Use and Land Cover Change on Groundwater Recharge and Quality in the Southwestern US. Global Change Biology, 11, 1577-1593. https://doi.org/10.1111/j.1365-2486.2005.01026.x

[4] Zhang, W., Kinniburgh, D. and Gabos, S. (2013) Assessment of Groundwater Quality in Alberta, Canada Using GIS Mapping. 3rd International Conference Medical, Biological and Paramedical Science, Bali, 199-203.

[5] Vijay, R., Samal, D.R. and Mohapatra, P.K. (2001) GIS Based Identification and Assessment of Groundwater Quality Potential Zones in Puri City, India. Journal of Water Resource and Protection, 3, 440-447. https://doi.org/10.4236/jwarp.2011.36054

[6] Geetha Selvarani, A. and Elangovan, K. (2009) Hydrogeochemistry Analysis of Groundwater in Noyyal River Basin, Tamilnadu, India. International Journal of Applied Environmental Sciences, 4, 211-227.

[7] Geetha Selvarani, A. and Elangovan, K. (2008) Assessment of Groundwater Quality of Noyyal River Basin. Journal of Indian Association for Environmental Management, 35, 133-138.

[8] Amer, R., Ripperdan, R., Wang, T. and Encarnacio'n, J. (2012) Groundwater Quality and Management in Arid and Semi-Arid Regions: Case Study, Central Eastern Desert of Egypt. Journal of African Earth Sciences, 69, 13-25.

https://doi.org/10.1016/j.jafrearsci.2012.04.002

[9] Chaudhary, B.S., Saroha, G.P. and Yadav, Manoj (2008) Human Induced Land Use/Land Cover Changes in Northern Part of Gurgaon District, Haryana, India Natural Resources Census Concept. Journal of Human Ecology, 23, 243-252.

[10] Krishnaraj, S., Kumar, S. and Elango, K.P. (2015) Spatial Analysis of Groundwater Quality Using Geographic Information System a Case Study. IOSR Journal of Environmental Science, Toxicology and Food Technology, 9, 01-06.

[11] Venkateswaran, S., Elangomannan, M. and Vijay Prabhu, M. (2012) Evaluation of Physico-Chemical Characteristics in Groundwater Using GIS-A Case Study of Chinnar Sub-Basin of Cauvery River, Tamil Nadu, India. Ultra Scientist, 24, 387398.

[12] Venkateswaran, S. and Deepa, S. (2013) Assessment of Groundwater Quality Using GIS Techniques in Vaniyar Watershed, Ponnaiyar River, Tamil Nadu. ICWRCOE 2015, 4, 1283-1290.

[13] Nas, B. and Berktay, A. (2010) Groundwater Quality Mapping in Urban Groundwater Using GIS. Environmental Monitoring and Assessment, 160, 215-227.

[14] Dinesh, C and Geetha Selvarani, A. (2016) Relationship between Landuse and Water Quality in Salem District. International Journal for Innovative Research in Science \& Technology, 2, 68-72.

[15] Singh, A.A., Singh, P.K., Dhakate, R. and Singh, N.P. (2013) Groundwater Quality Appraisal and Its Hydrochemical Characterization in Ghaziabad (A Region of Indo-Gangetic Plain), Uttar Pradesh, India. Applied Water Sciences, 3, 132-137.

[16] Sharma, T., Satya Kiran, P.V., Singh, T.P., Trivedi, A.V. and Navalgund, R.R. (2001) Hydrologic Response of a Watershed to Land Use Changes: A Remote Sensing and GIS Approach. International Journal of Remote Sensing, 22, 2095-2108. https://doi.org/10.1080/01431160117359

[17] Khan, H.H., Khan, A., Ahmed, S. and Perrin, J. (2011) GIS-Based Impact Assessment of Land-Use Changes on Groundwater Quality: Study from a Rapidly Urba- 
nizing Region of South India. Environmental Earth Sciences, 63, 1289-1302. https://doi.org/10.1007/s12665-010-0801-2

[18] Tu, J. and Xia, Z.G. (2008) Examining Spatially Varying Relationships between Land Use and Water Quality Using Geographically Weighted Regression I: Model Design and Evaluation. Science of the Total Environment, 407, 358-378. https://doi.org/10.1016/j.scitotenv.2008.09.031

[19] Senthilnathan, S.A. (2001) Micro Level Environment Status Report of River Noyyal Basin. Essemm Envirotech Company, Tiruppur.

[20] Appasamy, P. and Nelliyat, P. (2007) Compensating the Loss of Ecosystem Services Due to Pollution in Noyyal River Basin, Tamil Nadu. Madras School of Economics, Chennai, $7 \mathrm{p}$.

[21] Sankaraaj, L., Subramanian, T.P., Siddhamalai, A. and Farooque Ahmed, N. (2002) Quality of Soil and Water for Agriculture in Noyyal River Basin. Tamil Nadu', Joint Director of Agriculture (Research), Soil Survey and Land Use Organization, Tamil Nadu Department of Agriculture, Coimbatore, 2-4.

[22] Furn, K. (2004) Effects of Dyeing and Bleaching Industries on the Area around the Orathupalayam Dam in Southern India. This Study Was Carried Out within the Framework of a Scholarship Programme, Minor Field Study (MFS), Which Is Funded by the Swedish International Development Cooperation Agency (Sida).

[23] Shodhganga (2002) Profile of Noyyal River Basin. http://shodhganga.inflibnet.ac.in/bitstream/10603/33831/3/chapter3.pdf

[24] APHA (1995) Standard Methods for the Examination of Water and Waste Water. 19th Edition, American Public Health Association, Washington DC.

[25] BIS (1991) Drinking Water Specification, Bureau of Indian Standards. New Delhi, 10500. http://bis.org.in/bis/html/10500.html

[26] NRSA (1995) Integrated Mission for Sustainable Development (IMSD)-Technical Guidelines. National Remote Sensing Agency, Hyderabad.

[27] Srivastava K., Sinha, A. and Upadhyay, R. (2006) Monitoring Land Use/Land Cover of Maharajganj District of Uttar Pradesh Using Digital Remote Sensing Technique. Remote Sensing Applications Centre, U.P., Lucknow, 188-190.

Submit or recommend next manuscript to SCIRP and we will provide best service for you:

Accepting pre-submission inquiries through Email, Facebook, LinkedIn, Twitter, etc. A wide selection of journals (inclusive of 9 subjects, more than 200 journals)

Providing 24-hour high-quality service

User-friendly online submission system

Fair and swift peer-review system

Efficient typesetting and proofreading procedure

Display of the result of downloads and visits, as well as the number of cited articles

Maximum dissemination of your research work

Submit your manuscript at: http://papersubmission.scirp.org/

Or contact gep@scirp.org 